\title{
CORRESPONDENCE
}

\section{REMARKS ON DR. LAMONT'S INTERPRETATION OF FEATURES IN THE TRILOBITE PLATYCALYMENE}

SiR,-In a recent number (Geol. Mag., lxxxvi, 1949, 313, 314) Dr. Lamont records that Platycalymene duplicata (Murchison) has two pairs of anterior pits lying in the axial furrows each pair respectively in front of and behind the ocular ridges. He claims that these point to a trisegmental origin of the frontal lobe of the glabella, a claim here considered to be based upon a misapprehension.

The anterior pair of pits seen in $P$. duplicata are familiar features among various of the Calymenid genera - these are the "antennary" pits of Shirley's descriptions (Quart. Journ. Geol. Soc., 1936). Platycalymene shares with Metacalymene and Pharostoma, among Calymenid genera, the presence of an ocular ridge or eye-line. Now, it is frequent in trilobites that when a ridging occurs in the exoskeleton there is a tendency for the development proximally of a complementary furrow. As examples may be quoted the cephalic marginal rim and marginal furrow, also the palpebral lobe and palpebral furrow seen in several genera. In a specimen of Platycalymene duplicata from Pencerrig, Builth, preserved in the Geological Survey and Museum, numbered 19565, the cranidial shield shows such a complementary furrow behind the ocular ridge and the ridge crosses the axial furrow to merge into the frontal lobe of the glabella, and in so doing it takes with it the complementary furrow which impresses itself into the axial furrow, forming the hindermost of the two anterior pits to which Dr. Lamont draws attention. It is possible that this hindermost pit had some indirect relationship to a corresponding hypostomial structure, but it is very doubtful whether it has any bearing on the primary segmentation of the trilobite head.

The presence of a near ally of $P$. duplicata at Newtown, Co. Waterford, has long been known, e.g. Salter, Monograph of the British Trilobites, 1865, p. 101 ; Stubblefield, Geol. Mag., 1939, p. 59. The Newtown cranidium, collected by Austin nearly 100 years ago, to which these previous writers have referred, is preserved in the Geological Survey and Museum and numbered 56721 ; it is not compressed laterally in distinction from the appearance of Dr. Lamont's holotype of his species $P$. éire. The pre-ocular course of the facial sutures is much as Dr. Lamont describes, though that author is inaccurate in his description of the course in $P$. duplicata from Builth. As shown by Salter, op. cit., pl. ix, fig. 20, in $P$. duplicata, the pre-ocular courses are parallel for the greater part of their length, as in $P$. éire; furthermore, judging from Austin's specimen, the undistorted anterior border-rims are similar in the two species, as also is the distribution of the glabellar furrows. The tendency for the lateral parts of the occipital ring to point forwards exists not only in Dr. Lamont's material of $P$. eire but also in some P. duplicata, e.g. G.S.M. specimen 19557 ; this may be a preservational feature resulting from differing pressures; the Austin specimen does not show such a tendency. It is, of course, conceivable that Dr. Lamont's specimen of $P$. éire is not conspecific with the fossil collected by Austin from Newtown; but with Dr. Lamont's description in print, without reference to the earlier Austin specimen, it is likely that the latter would be taken in default as $P$. éire by workers unfamiliar with the material, and the remarkably close resemblance between Austin's specimen and the Builth $P$. duplicato would be ignored. The major difference between these two forms appears to me to be that whereas in $P$. duplicata the occipital ring is $\frac{2}{3}$ to $\frac{3}{4}$ of the posterior width of one of the fixed cheeks, in the Irish specimen these are approximately equal in width; should better material come to hand from Dr. Lamont's locality this feature may be checked, and the true characters of $P$. éire may become established.

Geological Survey and Museum,

C. J. StubBlefield.

LONDON, S.W. 7.

December, 1949. 